\title{
Characterization of alkaliphilic Bacillus strains used in industry: proposal of five novel species
}

\author{
Yuichi Nogi, Hideto Takami and Koki Horikoshi \\ Extremobiosphere Research Center, Japan Agency for Marine-Earth Science and Technology, \\ 2-15 Natsushima-cho, Yokosuka 237-0061, Japan
}

Correspondence

Yuichi Nogi

nogiy@jamstec.go.jp

\section{INTRODUCTION}

Alkaliphilic Bacillus species have important industrial applications due to their ability to produce alkaline enzymes such as protease (Horikoshi, 1971), cyclomaltodextrin glucanotransferase (CGTase) (Yamamoto et al., 1972) and cellulase (Horikoshi et al., 1971). These species produce extracellular enzymes that are resistant to high $\mathrm{pH}$ and/or high temperature conditions (Nielsen et al., 1995; Horikoshi, 1999). Since Vedder (1934) first isolated the aerobic, endospore-forming, obligate alkaliphilic bacterium Bacillus alcalophilus, many obligately or facultatively alkaliphilic Bacillus strains have been isolated for use in industry, biotechnology and physiology (Horikoshi, 1999). However, the majority of these strains have not been identified at the species level. The aim of this study was to classify a collection of 20 industrially important alkaliphilic Bacillus strains at the species level.

\section{Abbreviation: CGTase, cyclomaltodextrin glucanotransferase.}

The GenBank/EMBL/DDBJ accession numbers for the 16S rRNA gene sequences of Bacillus wakoensis JCM 9140', Bacillus hemicellulosilyticus JCM 9152' ${ }^{\top}$, Bacillus cellulosilyticus JCM 9156' ${ }^{\top}$, Bacillus akibai JCM $9157^{\top}$ and Bacillus mannanilyticus JCM $10596^{\top}$ are $\mathrm{AB} 043851, \mathrm{AB} 043846, \mathrm{AB} 043852, \mathrm{AB} 043858$ and $\mathrm{AB} 043864$, respectively.

Tables detailing the growth characters, the utilization of carbohydrate substrates and fatty acid profiles of the five novel species are available as supplementary material in IJSEM Online.

\section{METHODS}

Bacterial strains and culture conditions. The alkaliphilic bacterial strains investigated in this study are listed in Table 1 . The strains were stored as a working collection at $5{ }^{\circ} \mathrm{C}$ on Horikoshi II agar slopes ( $10 \mathrm{~g}$ glucose, $5 \mathrm{~g}$ polypeptone, $5 \mathrm{~g}$ yeast extract, $10 \mathrm{~g} \mathrm{NaCl}$, $1 \mathrm{~g} \mathrm{~K}_{2} \mathrm{HPO}_{4}, 0 \cdot 2 \mathrm{~g} \mathrm{MgSO}_{4} .7 \mathrm{H}_{2} \mathrm{O}, 15 \mathrm{~g}$ agar, $900 \mathrm{ml}$ distilled water, $\mathrm{pH} 9$, to which $100 \mathrm{ml} 10 \% \mathrm{NaHCO}_{3}$ solution was added aseptically after autoclaving).

Standard bacteriological characterization. Growth experiments at $\mathrm{pH}$ 6-11 were performed on Horikoshi II broth adjusted to various $\mathrm{pH}$ values: $\mathrm{pH} 6$ (adjusted by adding $\mathrm{HCl}$ ), $\mathrm{pH} 7-9$ (adjusted by adding $\mathrm{NaHCO}_{3}$ ) and $\mathrm{pH} 10-11$ (adjusted by adding $\mathrm{Na}_{2} \mathrm{CO}_{3}$ ). Growth at various $\mathrm{NaCl}$ concentrations $(0-15 \%)$ and at various temperatures $\left(10-60{ }^{\circ} \mathrm{C}\right)$ was investigated in Horikoshi II broth $(\mathrm{pH} 9)$. Utilization of carbohydrates was determined with the Biolog automatic identification system, according to the manufacturer's recommendations. Other standard tests were performed by following the general procedures described in Cowan \& Steel's manual (Barrow \& Feltham, 1993).

Cellular fatty acids and respiratory lipoquinones. Alkaliphilic Bacillus strains were cultured in Horikoshi II broth at $\mathrm{pH} 9$ and $30{ }^{\circ} \mathrm{C}$ for 2 days, under which conditions all strains exhibited growth. Cells were washed twice with $0.7 \% \mathrm{NaCl}$ at $4{ }^{\circ} \mathrm{C}$ followed by centrifugation at $8000 \mathrm{~g}$ and freeze-drying. Dried cells $(20 \mathrm{mg})$ were placed in Teflon-lined, screw-capped tubes containing $2 \mathrm{ml}$ anhydrous methanolic $\mathrm{HCl}$ and heated to $100{ }^{\circ} \mathrm{C}$ for $3 \mathrm{~h}$. After cooling, $1 \mathrm{ml}$ water was added and the fatty acid methyl esters were extracted with $n$-hexane. Samples were analysed for cellular fatty acids using a gas-liquid chromatography/mass spectrometer (Komagata \& Suzuki, 1987). 
Table 1. Alkaliphilic Bacillus strains investigated in this study

CGTase, Cyclomaltodextrin glucanotransferase; CMCase, carboxymethyl cellulase. BspO4I is a restriction enzyme.

\begin{tabular}{|c|c|c|}
\hline Strain & Product & Reference \\
\hline O-4 (=JCM 9137=DSM 2514) & Protease, BspO4I & Horikoshi \& Ikeda (1970) \\
\hline $\mathrm{N}-1^{\mathrm{T}}\left(=\mathrm{JCM} 9140^{\mathrm{T}}=\mathrm{DSM} 2521^{\mathrm{T}}\right)$ & Cellulase & Horikoshi et al. (1971) \\
\hline 17-1 ( = JCM 9142=DSM 2524) & Amylase, CGTase & Yamamoto et al. (1972) \\
\hline 27-1 (=JCM 9144=DSM 2520) & Amylase & Yamamoto et al. (1972) \\
\hline 13 (=JCM 9145=DSM 2523) & Amylase, CGTase & Yamamoto et al. (1972) \\
\hline K-12-5 ( = JCM 9149) & $\beta$-1,3-Glucanase & Horikoshi \& Atsukawa (1973) \\
\hline 202-1 ( = JCM 9151) & Pullulanase & Nakamura et al. (1975) \\
\hline C-11 $1^{\mathrm{T}}\left(=\mathrm{JCM} 9152^{\mathrm{T}}=\right.$ DSM $\left.16731^{\mathrm{T}}\right)$ & Hemicellulase & Ikura \& Horikoshi (1977) \\
\hline D-6 ( = JCM 9154) & Protease & Horikoshi \& Akiba (1982) \\
\hline 2b-2 ( = JCM 9155) & & Kudo \& Horikoshi (1983) \\
\hline $\mathrm{N}-4^{\mathrm{T}}\left(=\mathrm{JCM} 9156^{\mathrm{T}}=\mathrm{DSM} 2522^{\mathrm{T}}\right)$ & Cellulase & Horikoshi et al. (1971) \\
\hline $1139^{\mathrm{T}}\left(=\mathrm{JCM} 9157^{\mathrm{T}}=\right.$ ATCC $\left.43226^{\mathrm{T}}\right)$ & CMCase & Fukumori et al. (1985) \\
\hline IC ( = JCM 9158) & Enolase & Kitada et al. (1987) \\
\hline KX-6 ( = JCM 9159) & $\mathrm{D}$-Xylose isomerase & Kwon et al. (1987) \\
\hline H-167 (=JCM 9160) & Amylase & Hayashi et al. (1988) \\
\hline 199 ( = JCM 9163) & Cyclomaltodextrinase & Yoshida et al. (1991) \\
\hline C-3 ( = JCM 9164) & $5^{\prime}$-Nucleotidase & Ikura \& Horikoshi (1989) \\
\hline S-2 ( = JCM 9166) & Galactanase & Tsumura et al. (1991) \\
\hline $\begin{array}{l}\text { AM-001 } 1^{\mathrm{T}}\left(=\mathrm{JCM} 10596^{\mathrm{T}}=\right. \\
\left.\text { DSM } 16130^{\mathrm{T}}\right)\end{array}$ & $\beta$-Mannosidase, $\beta$-mannanase & Akino et al. (1987) \\
\hline 8-1 (=JCM 10598) & Protease & Kitada \& Horikoshi (1976) \\
\hline
\end{tabular}

Isoprenoid quinones were extracted with chloroform/methanol $(2: 1)$ from dried cells $(200 \mathrm{mg})$ and purified on TLC. The purified isoprenoid quinones were analysed using reverse-phase HPLC (Komagata \& Suzuki, 1987).

Genotypic characterization. Chromosomal DNA was purified using a standard method (Saito \& Miura, 1963). The DNA G+C content was determined using reverse-phase HPLC (Tamaoka \& Komagata, 1984). For analysis of relatedness, DNA-DNA hybridization was carried out at $40{ }^{\circ} \mathrm{C}$ for $4 \mathrm{~h}$ and measured fluorometrically using the method of Ezaki et al. (1989).

$16 \mathrm{~S}$ rRNA gene sequences were obtained by direct sequencing of PCR-amplified DNA as described previously (Kato et al., 1998). Nucleotide substitution rates $\left(K_{\text {nuc }}\right)$ (Kimura, 1980) were determined and a distance matrix tree was constructed with the neighbourjoining method (Saitou \& Nei, 1987) using the CLUSTAL_X program (Thompson et al., 1997). Alignment gaps and unidentified base positions were not taken into consideration for the calculations. The topology of the phylogenetic tree was evaluated by performing a bootstrap analysis with 1000 replicates. The GenBank/EMBL/ DDBJ accession numbers for the 16S rRNA gene sequences of the isolates are shown in Fig. 1. Other reference sequences were obtained from the GenBank database.

\section{RESULTS AND DISCUSSION}

\section{5 rRNA-based phylogeny and DNA-DNA relatedness}

To investigate the taxonomic position of the 20 alkaliphilic Bacillus strains, 16S rRNA gene sequence analysis and genomic DNA-DNA hybridization studies were performed. The generally recommended and accepted criteria for delineating bacterial species state that strains with a DNA-DNA relatedness of less than $70 \%$ as measured by hybridization or with a $16 \mathrm{~S}$ rRNA gene sequence dissimilarity greater than $3 \%$ are considered to belong to separate species (Wayne et al., 1987; Stackebrandt \& Goebel, 1994; Stackebrandt et al., 2002). However, bacterial strains with a difference in $16 \mathrm{~S}$ rRNA gene sequence of less than $3 \%$ cannot be allocated to the same species without support from DNA-DNA relatedness studies. In the 16S rRNA gene sequence clustering, 12 groups of strains that showed a high degree of internal sequence similarity $(98 \cdot 3-99 \cdot 7 \%)$ could be delineated. In the neighbour-joining tree, the sequences form a distinct lineage, with alkaliphilic Bacillus species as the closest relatives (Fig. 1).

The DNA-DNA hybridization values between Bacillus clausii DSM $8716^{\mathrm{T}}$ and strains $\mathrm{O}-4, \mathrm{H}-167$ and $\mathrm{IC}$ were greater than $89 \%$ and therefore these three strains were identified as $B$. clausii. DNA-DNA relatedness values between Bacillus pseudofirmus DSM $8715^{\mathrm{T}}$ and strains 8-1, $2 \mathrm{~b}-2$ and 27-1 were greater than $80 \%$ and therefore these three strains were identified as B. pseudofirmus. For Bacillus halodurans DSM $497^{\mathrm{T}}$ and strains C-3 and 202-1, DNADNA relatedness was greater than $93 \%$ and therefore these two strains were identified as $B$. halodurans. Between Bacillus cohnii DSM $6307^{\mathrm{T}}$ and strains D-6 and 199, DNADNA relatedness was greater than $78 \%$ and therefore 


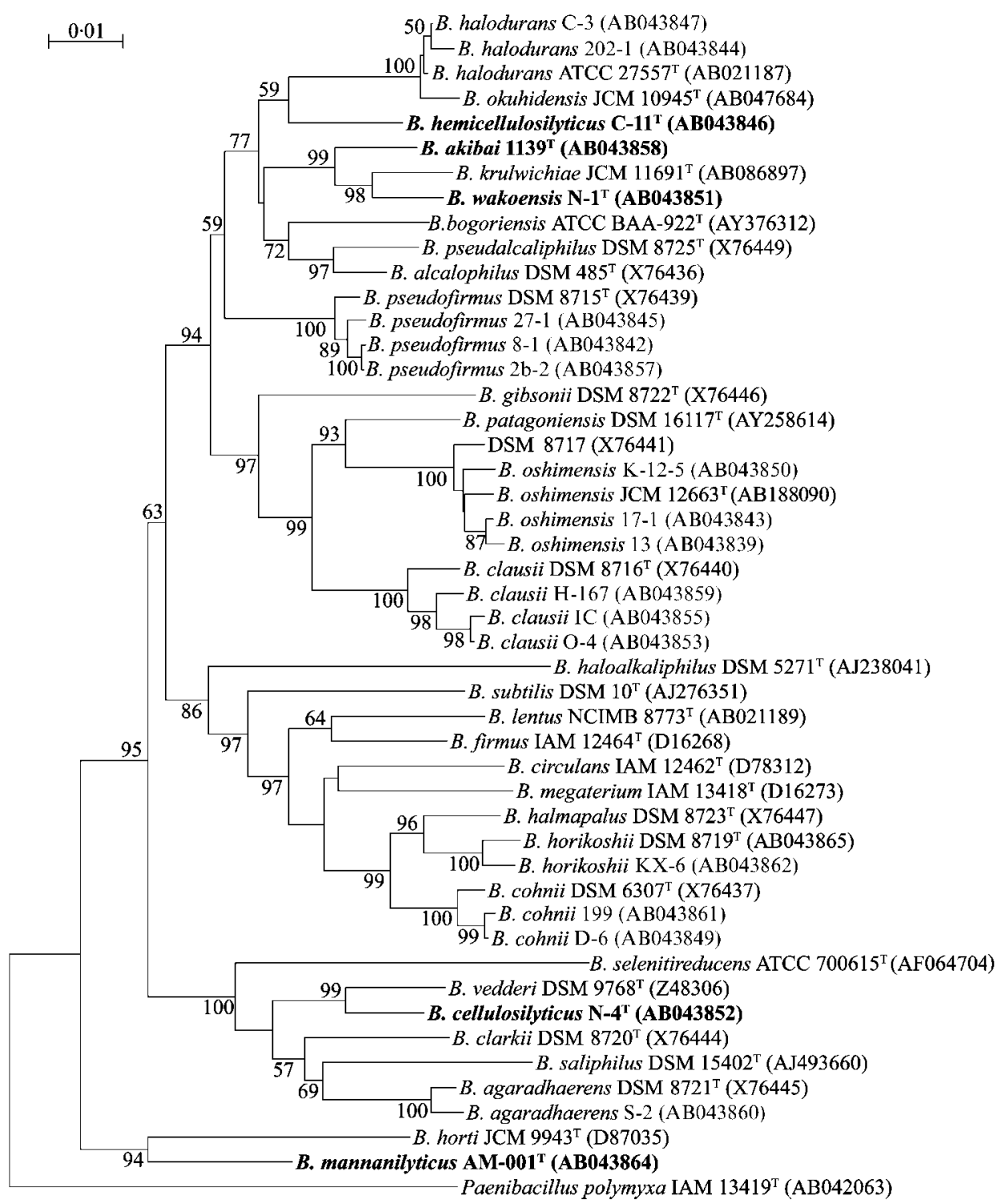

Fig. 1. Phylogenetic tree showing the relationships of the identified alkaliphilic bacterial strains and the type strains of closely related Bacillus species, constructed using the neighbour-joining method and based on 16S rRNA gene sequences. GenBank accession numbers are given in parentheses. Bootstrap values were calculated from multiple resamplings of the sequence dataset, which are the basis for multiple tree topologies. Bar, 0.01 nucleotide substitutions per site.

these two strains were identified as B. cohnii. The DNADNA hybridization value of $98 \%$ indicated that Bacillus agaradhaerens DSM $8721^{\mathrm{T}}$ and strain S-2 represent the same species and a value of $70 \%$ indicated that Bacillus horikoshii DSM $8719^{\mathrm{T}}$ and strain KX-6 also represent the same species.

The 16S rRNA gene sequence analysis showed that strains $13,17-1, \mathrm{~K}-12-5$ and DSM 8717 are closely related to each other $(99 \cdot 1-99 \cdot 7 \%)$. The DNA-DNA reassociation values among strains $13,17-1, \mathrm{~K}-12-5$ and DSM 8717 were greater than $80 \%$ and therefore these four strains were identified as representatives of the same species. According to the sequence similarity values and results of the phylogenetic analysis based on these 16S rRNA gene sequences, these strains are most closely related to Bacillus oshimensis JCM $12663^{\mathrm{T}}(98 \cdot 4-98 \cdot 5 \%)$. The DNA-DNA reassociation value between strain DSM 8717 and B. oshimensis JCM $12663^{\mathrm{T}}$ was $67 \cdot 6 \%$ (Yumoto et al., 2005). Yumoto et al. (2005) found seven characteristics that differentiated B. oshimensis JCM $12663^{\mathrm{T}}$ from DSM 8717. In this study, three of these characteristics, hydrolysis of Tweens 20, 40 and 60, were found to be the same for B. oshimensis JCM $12663^{\mathrm{T}}$ and DSM 8717 and another of these characteristics, lower temperature for growth, was found to be variable for each strain. On the basis of these observations, these strains were 
identified as representatives of the same species. However, according to the results of the 16S rRNA gene sequence analysis, strains $\mathrm{N}-1^{\mathrm{T}}$ and $1139^{\mathrm{T}}$ were closely related to Bacillus krulwichiae JCM $11691^{\mathrm{T}}(97 \cdot 4$ and $96 \cdot 1 \%$, respectively, and between strain $\mathrm{N}-1^{\mathrm{T}}$ and $1139^{\mathrm{T}}$ the sequence similarity value was $97 \cdot 1 \%$ ), but the DNA-DNA relatedness values between strains $\mathrm{N}-1^{\mathrm{T}}$ and $1139^{\mathrm{T}}$ and $B$. krulwichiae JCM $11691^{\mathrm{T}}$ were less than $30 \%$, and therefore these strains were identified as representing a novel species.

In the $16 \mathrm{~S}$ rRNA gene sequence analysis, strain $\mathrm{C}-11^{\mathrm{T}}$ was closely related to Bacillus alcalophilus DSM $485^{\mathrm{T}}(96 \cdot 3 \%), B$. halodurans ATCC $27557^{\mathrm{T}}(96 \cdot 1 \%)$, Bacillus okuhidensis JCM $10945^{\mathrm{T}}(96 \cdot 1 \%)$ and strain $1139^{\mathrm{T}}(96 \cdot 3 \%)$, but the respective DNA-DNA reassociation values between strain $\mathrm{C}-11^{\mathrm{T}}$ and these type strains were less than $25 \%$, and therefore this strain was identified as representing a novel species. The $16 \mathrm{~S}$ rRNA gene sequence analysis showed that strain $\mathrm{N}-4^{\mathrm{T}}$ was closely related to Bacillus vedderi DSM $9768^{\mathrm{T}}(97 \cdot 4 \%)$, but the DNA-DNA reassociation value between strain $\mathrm{N}-4^{\mathrm{T}}$ and this type strain was less than $27 \%$ and therefore this strain was identified as representing a novel species. In the $16 \mathrm{~S}$ rRNA gene sequence analysis of strain $\mathrm{AM}-001^{\mathrm{T}}$, the highest similarity was observed with Bacillus horti JCM $9943^{\mathrm{T}}(94 \cdot 1 \%)$. The DNA-DNA relatedness value between strain $\mathrm{AM}-001^{\mathrm{T}}$ and this type strain was less than $20 \%$ and therefore this strain was identified as representing a novel species.

\section{Physiological and biochemical characteristics}

Phenotypic characteristics of the 20 alkaliphilic Bacillus strains and alkaliphilic Bacillus type strains are shown in Table 2 and in Supplementary Table S1 in IJSEM Online, respectively. The utilization of carbohydrate substrates for the novel species, as deduced from the Biolog tests, is shown in Supplementary Table S2 in IJSEM Online. A comparison of the physiological and biochemical characteristics of the five groups showed some differences when compared with the type strains and with each other. Strain $\mathrm{N}-1^{\mathrm{T}}$ and $B$. pseudoalcalophilus grew at similar temperatures $\left(10-40{ }^{\circ} \mathrm{C}\right)$, $\mathrm{pH}(8-10)$ and $\mathrm{NaCl}$ concentration $(0-10 \%)$, but showed varying results for the hydrolysis of casein and gelatin and for the reduction of nitrate. Strains $\mathrm{C}-11^{\mathrm{T}}$ and $\mathrm{N}-1^{\mathrm{T}}$ grew at similar temperatures, $\mathrm{pH}$ and $\mathrm{NaCl}$ concentrations $\left(\mathrm{C}-11^{\mathrm{T}}\right.$ : $10-40{ }^{\circ} \mathrm{C}, \mathrm{pH} 8-11,0-12 \% \mathrm{NaCl} ; \mathrm{N}-1^{\mathrm{T}}: 20-40{ }^{\circ} \mathrm{C}, \mathrm{pH}$ 8-10, $0-12 \% \mathrm{NaCl})$ as B. clarkii $\left(20-45^{\circ} \mathrm{C}, \mathrm{pH} 8-11,0-12 \%\right.$ $\mathrm{NaCl}$ ) and $B$. krulwichiae (temperature range not determined, $\mathrm{pH} 8-10,0-12 \% \mathrm{NaCl}$ ), although their hydrolysis of casein and gelatin and their menaquinone content were different. Strain $\mathrm{C}-11^{\mathrm{T}}$ also showed characteristic utilization of the carbohydrate substrates D-melibiose, D-raffinose and stachyose. Strain $1139^{\mathrm{T}}$ and B. cohnii displayed growth at similar temperatures, $\mathrm{pH}$ and $\mathrm{NaCl}$ concentrations $\left(20-45^{\circ} \mathrm{C}, \mathrm{pH} 8-11,0-7 \% \mathrm{NaCl}\right)$, although they are phylogenetically separate and their hydrolysis of casein and gelatin is different. Strain $1139^{\mathrm{T}}$ utilized various carbohydrates. Strain $\mathrm{AM}-001^{\mathrm{T}}$ showed characteristics unlike those of any other strain and utilized a limited range of carbohydrates.

\section{Fatty acid analysis}

Almost all of the whole-cell fatty acid profiles of the alkaliphilic Bacillus strains grown at $\mathrm{pH} 9$ consisted of the major fatty acids iso- $\mathrm{C}_{15: 0}$ and anteiso- $\mathrm{C}_{15: 0}$, except for the profile of strain AM- $001^{\mathrm{T}}$ (see Supplementary Table S3 in IJSEM Online). Most of the whole-cell fatty acid content of strain $\mathrm{AM}-001^{\mathrm{T}}$ was $\mathrm{C}_{16: 0}$ and $\mathrm{C}_{16: 1}$, which differed markedly from those of the other strains. Strains $\mathrm{N}-4^{\mathrm{T}}$, $\mathrm{C}-11^{\mathrm{T}}, \mathrm{N}-1^{\mathrm{T}}$ and $1139^{\mathrm{T}}$ also contained slightly more $\mathrm{C}_{16: 0}$ and slightly less iso- $\mathrm{C}_{15: 0}$ compared with other strains (Supplementary Table S3 in IJSEM Online). Strain $1139^{\mathrm{T}}$ had more fatty acids of comparatively short chain length, such as iso- $\mathrm{C}_{14: 0}$ or $\mathrm{C}_{14: 0}$, compared with other strains.

On the basis of these chemotaxonomic and phylogenetic studies, five novel alkaliphilic Bacillus species are proposed.

\section{Description of Bacillus wakoensis sp. nov.}

Bacillus wakoensis (wa.ko.en'sis. N.L. masc. adj. wakoensis of Wako, a city in Japan).

Cells are rod-shaped, $1 \cdot 5-2 \cdot 0 \mu \mathrm{m}$ in length and $0 \cdot 5-0 \cdot 8 \mu \mathrm{m}$ in width, Gram-positive. Cells are motile by peritrichous flagella and produce spores that are ellipsoidal and located terminally in the sporangium, which is swollen. Colonies are circular and yellowish. Grows between 10 and $40{ }^{\circ} \mathrm{C}$, with the optimum at around $37^{\circ} \mathrm{C}$. The range of $\mathrm{pH}$ for growth is from 8 to 10 , with the optimum at $\mathrm{pH} 9-10$. Tests positive for catalase, for hydrolysis of starch and cellulose and for nitrate reduction. It is negative for hydrolysis of Tweens 20 , 40 and 60, casein, gelatin and oxidase and for the production of indole and $\mathrm{H}_{2} \mathrm{~S}$. Acid is produced from arbutin, cellobiose, D-fructose, glucose, D-maltose, D-mannitol, D-mannose, D-psicose, salicin, D-sorbitol, sucrose, Dtrehalose, turanose and D-xylose; no gas evolution occurs from these carbohydrates. The organism can grow at an $\mathrm{NaCl}$ concentration of $10 \%(\mathrm{w} / \mathrm{v})$. The major isoprenoid quinone types are MK-6 and MK-7. Major fatty acids are iso- $\mathrm{C}_{15: 0}$, anteiso- $\mathrm{C}_{15: 0}$ and $\mathrm{C}_{16: 0}$. The genomic DNA $\mathrm{G}+\mathrm{C}$ content is $38 \cdot 1 \mathrm{~mol} \%$, as determined by HPLC.

The type strain is $\mathrm{N}-1^{\mathrm{T}}\left(=\mathrm{JCM} 9140^{\mathrm{T}}=\mathrm{DSM} 2521^{\mathrm{T}}\right)$.

\section{Description of Bacillus hemicellulosilyticus sp. nov.}

Bacillus hemicellulosilyticus (hem.i.cell.u.lo.si.ly'ti.cus. N.L. neut. n. hemicellulosum hemicellulose; Gr. adj. lutikos able to loosen, able to dissolve; N.L. masc. adj. hemicellulosilyticus hemicellulose-dissolving).

Cells are rod-shaped, $2 \cdot 0-6 \cdot 0 \mu \mathrm{m}$ in length and $0 \cdot 3-0 \cdot 5 \mu \mathrm{m}$ in width, Gram-variable. Cells are motile by peritrichous flagella and produce spores that are ellipsoidal and located terminally in the sporangium, which is swollen. Colonies are circular and white. It grows at between 10 and $40^{\circ} \mathrm{C}$, with the optimum at around $37^{\circ} \mathrm{C}$. The range of $\mathrm{pH}$ for growth is from 8 to 11, with the optimum at around $\mathrm{pH} 10$. Tests 
Table 2. Phenotypic characteristics of the novel and other alkaliphilic Bacillus species

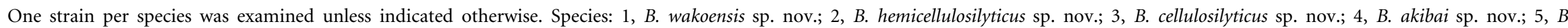

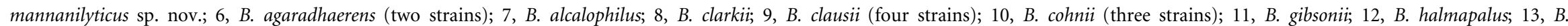

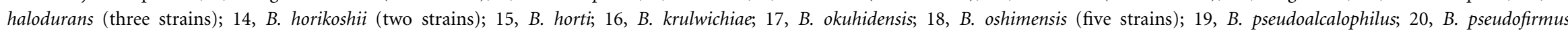

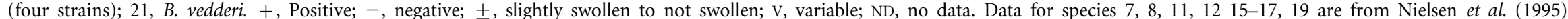
Yumoto et al. 1998, 2003, Li et al. (2002) and Agnew et al. (1995). Data for species 18 are from Yumoto et al. (2005) and this study.

\begin{tabular}{|c|c|c|c|c|c|c|c|c|c|c|c|c|c|c|c|c|c|c|c|c|c|}
\hline Characteristic & 1 & 2 & 3 & 4 & 5 & 6 & 7 & 8 & 9 & 10 & 11 & 12 & 13 & 14 & 15 & 16 & 17 & 18 & 19 & 20 & 21 \\
\hline $\begin{array}{l}\text { Spore } \\
\text { location }^{*}\end{array}$ & $\mathrm{~T}$ & $\mathrm{~T}$ & ST & ST & $\mathrm{T}$ & ST & ST & ST & STC & $\mathrm{T}$ & STC & STC & ST & ST & ST & ST & $\mathrm{T}$ & STT & STC & STC & $\mathrm{T}$ \\
\hline $\begin{array}{l}\text { Swollen } \\
\text { sporangia }\end{array}$ & + & + & + & \pm & + & + & - & + & \pm & + & - & - & \pm & \pm & $\mathrm{ND}$ & - & - & \pm & + & - & + \\
\hline \multicolumn{22}{|l|}{$\begin{array}{l}\text { Hydrolysis } \\
\text { of: }\end{array}$} \\
\hline Casein & - & - & - & - & + & - & + & + & + & $\mathrm{V}$ & + & + & + & + & + & $\mathrm{V}$ & + & + & + & + & - \\
\hline Gelatin & - & - & - & - & + & - & + & + & + & + & + & + & + & + & + & $\mathrm{V}$ & + & + & + & + & + \\
\hline Starch & + & - & + & + & + & - & + & + & + & + & + & + & + & + & + & + & + & + & + & + & - \\
\hline Tween 20 & - & + & + & + & - & - & $\mathrm{V}$ & - & - & $\mathrm{V}$ & - & - & $\mathrm{v}$ & - & - & + & - & + & - & - & $\mathrm{ND}$ \\
\hline Tween 40 & - & + & + & + & + & + & + & + & - & $\mathrm{V}$ & $\mathrm{V}$ & - & + & $\mathrm{V}$ & - & + & - & + & $\mathrm{V}$ & + & $\mathrm{ND}$ \\
\hline Tween 60 & - & + & + & + & + & + & + & + & - & + & $\mathrm{V}$ & - & + & $\mathrm{V}$ & - & + & - & + & $\mathrm{V}$ & + & $\mathrm{ND}$ \\
\hline $\begin{array}{l}\text { Reduction } \\
\text { of nitrate }\end{array}$ & + & - & + & + & + & + & $\mathrm{V}$ & + & + & + & $\mathrm{V}$ & - & $\mathrm{V}$ & - & + & + & + & - & - & - & ND \\
\hline \multicolumn{22}{|l|}{$\begin{array}{l}\text { Menaquinone } \\
\text { content }(\%) \text { : }\end{array}$} \\
\hline MK-5 & & & & & & & & & & & & & & & & 3 & & & & & \\
\hline MK-6 & 5 & & 1 & 5 & & 1 & 21 & & 13 & 1 & 93 & 3 & 11 & & 4 & 28 & & 2 & 13 & 55 & \\
\hline $\begin{array}{l}\text { MK-7 } \\
\text { MK-8 }\end{array}$ & 95 & 100 & 99 & 95 & 100 & 99 & 79 & 100 & 87 & 99 & 7 & 97 & 89 & $\begin{array}{r}99 \\
1\end{array}$ & 96 & 69 & $\mathrm{ND}$ & 98 & 87 & 45 & 100 \\
\hline $\begin{array}{l}\text { DNA G +C } \\
\text { content } \\
(\mathrm{mol} \%)\end{array}$ & $38 \cdot 1$ & $36 \cdot 8$ & $39 \cdot 6$ & $34 \cdot 4$ & $37 \cdot 4$ & $\begin{array}{c}36 \cdot 5- \\
36 \cdot 8\end{array}$ & $\begin{array}{c}36 \cdot 2- \\
38 \cdot 4\end{array}$ & $\begin{array}{c}42 \cdot 4- \\
43 \cdot 0\end{array}$ & $\begin{array}{l}41 \cdot 7- \\
43 \cdot 5\end{array}$ & $\begin{array}{c}33 \cdot 8- \\
35 \cdot 0\end{array}$ & $\begin{array}{l}40 \cdot 6- \\
41 \cdot 7\end{array}$ & $38 \cdot 6$ & $\begin{array}{c}41 \cdot 5- \\
41 \cdot 9\end{array}$ & $\begin{array}{c}39 \cdot 8- \\
40 \cdot 7\end{array}$ & $\begin{array}{c}40 \cdot 2- \\
40 \cdot 9\end{array}$ & $\begin{array}{c}40 \cdot 6- \\
41 \cdot 5\end{array}$ & $\begin{array}{l}41 \cdot 0- \\
41 \cdot 1\end{array}$ & $\begin{array}{c}39 \cdot 1- \\
40 \cdot 8\end{array}$ & $\begin{array}{c}38 \cdot 2- \\
39 \cdot 0\end{array}$ & $\begin{array}{l}38 \cdot 7- \\
40 \cdot 9\end{array}$ & $38 \cdot 3$ \\
\hline
\end{tabular}

${ }^{*}$ ST, subterminal; STC, subterminal to central; STT, subterminal to terminal; T, terminal. 
positive for catalase and for the hydrolysis of Tweens 20, 40 and 60 and hemicellulose. It is negative for oxidase, hydrolysis of soluble starch, gelatin and casein, for the production of indole and $\mathrm{H}_{2} \mathrm{~S}$ and for nitrate reduction. Acid is produced from arbutin, cellobiose, D-fructose, D-glucose, D-lactose, D-maltose, maltotriose, D-mannose, D-mannitol, D-melibiose, palatinose, D-raffinose, salicin, D-sorbitol, stachyose, sucrose, D-trehalose and turanose; no gas evolution occurs from these carbohydrates. The organism can grow at an $\mathrm{NaCl}$ concentration of $12 \%$ $(\mathrm{w} / \mathrm{v})$, but not at $15 \%$. The major isoprenoid quinone type is MK-7. Major fatty acids are iso- $C_{15: 0}$, anteiso- $C_{15: 0}, C_{16: 0}$ and anteiso- $\mathrm{C}_{17: 0}$. The genomic DNA $\mathrm{G}+\mathrm{C}$ content is $36 \cdot 8 \mathrm{~mol} \%$, as determined by HPLC.

The type strain is C $-11^{\mathrm{T}}\left(=\mathrm{JCM} 9152^{\mathrm{T}}=\right.$ DSM $\left.16731^{\mathrm{T}}\right)$.

\section{Description of Bacillus cellulosilyticus sp. nov.}

Bacillus cellulosilyticus (cell.u.lo.si.ly'ti.cus. N.L. neut. n. cellulosum cellulose; Gr. adj. lutikos able to loosen, able to dissolve; N.L. masc. adj. cellulosilyticus cellulose-dissolving).

Cells are rod-shaped, $2 \cdot 0-3 \cdot 0 \mu \mathrm{m}$ in length and $0 \cdot 3-0 \cdot 4 \mu \mathrm{m}$ in width, Gram-positive. Cells are motile by peritrichous flagella and produce spores that are ellipsoidal and located subterminally in the sporangium, which is swollen. Colonies are circular to slightly irregular and cream-coloured. Grows at between 20 and $40^{\circ} \mathrm{C}$, with the optimum at around $37^{\circ} \mathrm{C}$. The range of $\mathrm{pH}$ for growth is from 8 to 10, with the optimum at around $\mathrm{pH} 9-10$. Tests positive for catalase and nitrate reduction and for the hydrolysis of soluble starch, Tweens 20, 40 and 60 and cellulose. It is negative for oxidase, for hydrolysis of gelatin and casein and for the production of indole and $\mathrm{H}_{2} \mathrm{~S}$. Acid is produced from arbutin, cellobiose, D-fructose, D-glucose, D-lactose, D-maltose, maltotriose, Dmannose, salicin, sucrose, D-trehalose and turanose; no gas evolution occurs from these carbohydrates. The organism can grow at an $\mathrm{NaCl}$ concentration of $12 \%(\mathrm{w} / \mathrm{v}) \mathrm{NaCl}$, but not at $15 \%$. The major isoprenoid quinone type is MK-7. Major fatty acids are iso- $\mathrm{C}_{15: 0}$, anteiso- $\mathrm{C}_{15: 0}$ and $\mathrm{C}_{16: 0}$. The genomic DNA G $+\mathrm{C}$ content is $39.6 \mathrm{~mol} \%$, as determined by HPLC.

The type strain is $\mathrm{N}-4^{\mathrm{T}}\left(=\mathrm{JCM} 9156^{\mathrm{T}}=\mathrm{DSM} 2522^{\mathrm{T}}\right)$.

\section{Description of Bacillus akibai sp. nov.}

Bacillus akibai (a.ki.ba'i. N.L. gen. n. akibai of Akiba, named after the Japanese microbiologist Teruhiko Akiba, who made fundamental contributions to the study of alkaliphilic bacteria).

Cells are rod-shaped, $3 \cdot 0-4 \cdot 0 \mu \mathrm{m}$ in length and $0 \cdot 6-0 \cdot 8 \mu \mathrm{m}$ in width, Gram-positive. Cells are motile by peritrichous flagella and produce spores that are ellipsoidal and located subterminally in the sporangium, which is slightly swollen. Colonies are circular and yellowish. It grows at between 20 and $45^{\circ} \mathrm{C}$, with the optimum at around $37^{\circ} \mathrm{C}$. The range of $\mathrm{pH}$ for growth is from 8 to 10 , with the optimum at around
$\mathrm{pH}$ 9-10. Tests positive for catalase, for nitrate reduction and for the hydrolysis of soluble starch, Tweens 20, 40 and 60 and cellulose. It is negative for oxidase, for hydrolysis of gelatin and casein and for the production of indole and $\mathrm{H}_{2} \mathrm{~S}$. Acid is produced from L-arabinose, arbutin, cellobiose, Dfructose, D-galactose, D-glucose, D-maltose, maltotriose, Dmannose, D-mannitol, D-melezitose, palatinose, D-psicose, salicin, D-sorbitol, sucrose, D-trehalose and turanose; no gas evolution occurs from these carbohydrates. The organism can grow at an $\mathrm{NaCl}$ concentration of $7 \%(\mathrm{w} / \mathrm{v})$, but not at $10 \%$. The major isoprenoid quinone types are MK-6 and MK-7. Major fatty acids are iso- $\mathrm{C}_{14: 0}$, iso- $\mathrm{C}_{15: 0}$, anteiso$\mathrm{C}_{15: 0}$ and $\mathrm{C}_{16: 0}$. The genomic DNA $\mathrm{G}+\mathrm{C}$ content is $34 \cdot 4 \mathrm{~mol} \%$, as determined by HPLC.

The type strain is $1139^{\mathrm{T}}\left(=\mathrm{JCM} 9157^{\mathrm{T}}=\right.$ ATCC $\left.43226^{\mathrm{T}}\right)$.

\section{Description of Bacillus mannanilyticus sp. nov.}

Bacillus mannanilyticus (mann.an.i.ly'ti.cus. N.L. neut. n. mannanum mannan; Gr. adj. lutikos able to loosen, able to dissolve; N.L. masc. adj. mannanilyticus mannandissolving).

Cells are rod-shaped, $3 \cdot 0-6 \cdot 0 \mu \mathrm{m}$ in length and $0 \cdot 6-0 \cdot 8 \mu \mathrm{m}$ in width, Gram-variable. Cells are motile by peritrichous flagella and produce spores that are ellipsoidal and located terminally in the sporangium, which is swollen. Colonies are circular and yellow. It grows at between 20 and $45^{\circ} \mathrm{C}$, with the optimum at around $37^{\circ} \mathrm{C}$. The range of $\mathrm{pH}$ for growth is from 8 to 10, with the optimum at around $\mathrm{pH}$ 9. The bacterium tests positive for catalase and for the hydrolysis of Tweens 40 and 60, soluble starch, gelatin, casein and mannan and is negative for oxidase, for the production of indole and $\mathrm{H}_{2} \mathrm{~S}$ and for nitrate reduction. Acid is produced from D-fructose, glucose, D-maltose, mannose, D-galactose, D-xylose, D-mannitol, sorbitol, D-trehalose, raffinose, sucrose, D-lactose, glycerol, inulin and starch; no gas evolution occurs from these carbohydrates. The organism can grow at an $\mathrm{NaCl}$ concentration of $3 \%(\mathrm{w} / \mathrm{v})$, but not at $5 \%$. The major isoprenoid quinone type is MK-7. Major fatty acids are $\mathrm{C}_{16: 0}$ and $\mathrm{C}_{16: 1}$. The genomic DNA G+C content is $37 \cdot 4 \mathrm{~mol} \%$, as determined by HPLC.

The type strain is $\mathrm{AM}-001^{\mathrm{T}} \quad\left(=\mathrm{JCM} \quad 10596^{\mathrm{T}}=\mathrm{DSM}\right.$ $\left.16130^{\mathrm{T}}\right)$.

\section{REFERENCES}

Agnew, M. D., Koval, S. F. \& Jarrell, K. F. (1995). Isolation and characterization of novel alkaliphiles from bauxite-processing waste and description of Bacillus vedderi sp. nov., a new obligate alkaliphile. Syst Appl Microbiol 18, 221-230.

Akino, T., Nakamura, N. \& Horikoshi, K. (1987). Production of $\beta$ mannosidase and $\beta$-mannanase by an alkalophilic Bacillus sp. Appl Microbiol Biotechnol 26, 323-327.

Barrow, G. I. \& Feltham, R. K. A. (1993). Cowan and Steel's Manual for the Identification of Medical Bacteria, 3rd edn. New York: Cambridge University Press. 
Ezaki, T., Hashimoto, Y. \& Yabuuchi, E. (1989). Fluorometric deoxyribonucleic acid-deoxyribonucleic acid hybridization in microdilution wells as an alternative to membrane filter hybridization in which radioisotopes are used to determine genetic relatedness among bacterial strains. Int J Syst Bacteriol 39, 224-229.

Fukumori, F., Kudo, T. \& Horikoshi, K. (1985). Purification and properties of a cellulase from alkalophilic Bacillus sp. no. 1139. J Gen Microbiol 131, 3339-3345.

Hayashi, T., Akiba, T. \& Horikoshi, K. (1988). Production and purification of new maltohexose-forming amylases from alkalophilic Bacillus sp. H-167. Agric Biol Chem 52, 443-448.

Horikoshi, K. (1971). Production of alkaline enzymes by alkalophilic microorganisms. Part I. Alkaline protease produced by Bacillus no. 221. Agric Biol Chem 36, 1407-1414.

Horikoshi, K. (1999). Alkaliphiles. Tokyo: Kodansha.

Horikoshi, K. \& Akiba, T. (1982). Alkalophilic Microorganisms: a New Microbial World. Tokyo: Japan Scientific Societies Press.

Horikoshi, K. \& Atsukawa, Y. (1973). $\beta$-1,3-Glucanase produced by alkalophilic bacteria Bacillus No. K-12-5. Agric Biol Chem 37, 1449-1456.

Horikoshi, K. \& Ikeda, Y. (1970). Manufacturing Method of Alkaline Protease. Japan patent no. 45-34535.

Horikoshi, K., Ikeda, Y. \& Nakao, M. (1971). Manufacturing Method of Cellulase. Japan patent no. 46-76685.

Ikura, Y. \& Horikoshi, K. (1977). Isolation and some properties of alkalophilic bacteria utilizing rayon waste. Agric Biol Chem 41, 1373-1377.

Ikura, Y. \& Horikoshi, K. (1989). Manganese dependent production of 5'-nucleotidase by alkalophilic Bacillus no. C-3. J Ferment Bioeng 67, 111-114.

Kato, C., Li, L., Nogi, Y., Nakamura, Y., Tamaoka, J. \& Horikoshi, K. (1998). Extremely barophilic bacteria isolated from the Mariana Trench, Challenger Deep, at a depth of 11,000 meters. Appl Environ Microbiol 64, 1510-1513.

Kimura, M. (1980). A simple method for estimating evolutionary rates of base substitutions through comparative studies of nucleotide sequences. J Mol Evol 16, 111-120.

Kitada, M. \& Horikoshi, K. (1976). Alkaline proteinase production from methyl acetate by alkalophilic Bacillus sp. J Ferment Technol 54, 383-392.

Kitada, M., Wijayanti, L. \& Horikoshi, K. (1987). Biochemical properties of a thermophilic alkalophile. Agric Biol Chem 51, 2429-2435.

Komagata, K. \& Suzuki, K. (1987). Lipid and cell-wall analysis in bacterial systematics. Methods Microbiol 19, 161-207.

Kudo, T. \& Horikoshi, K. (1983). The effect of $\mathrm{pH}$ on heatresistance of spores of alkalophilic Bacillus no. 2b-2. Agric Biol Chem 47, 403-404.

Kwon, H.-J., Kitada, M. \& Horikoshi, K. (1987). Purification and properties of D-xylose isomerase from alkalophilic Bacillus no. KX-6. Agric Biol Chem 51, 1983-1989.

Li, Z., Kawamura, Y., Shida, O., Yamagata, S., Deguchi, T. \& Ezaki, T. (2002). Bacillus okuhidensis sp. nov., isolated from the Okuhida spa area of Japan. Int J Syst Evol Microbiol 52, 1205-1209.
Nakamura, N., Watanabe, K. \& Horikoshi, K. (1975). Purification and some properties of alkaline pullulanase from a strain of no. 202-1, an alkalophilic microorganism. Biochim Biophys Acta 397, 188-193.

Nielsen, P., Fritze, D. \& Priest, F. G. (1995). Phenetic diversity of alkaliphilic Bacillus strains: proposal for nine new species. Microbiology 141, 1745-1761.

Saito, H. \& Miura, K. (1963). Preparation of transforming deoxyribonucleic acid by phenol treatment. Biochim Biophys Acta 72, 612-629.

Saitou, N. \& Nei, M. (1987). The neighbor-joining method: a new method for reconstructing phylogenetic trees. Mol Biol Evol 4, 406-425.

Stackebrandt, E. \& Goebel, B. M. (1994). Taxonomic note: a place for DNA-DNA reassociation and 16S rRNA sequence analysis in the present species definition in bacteriology. Int J Syst Bacteriol 44, 846-849.

Stackebrandt, E., Frederiksen, W., Garrity, G. M. \& 10 other authors (2002). Report of the ad hoc committee for the re-evaluation of the species definition in bacteriology. Int J Syst Evol Microbiol 52, 1043-1047.

Tamaoka, J. \& Komagata, K. (1984). Determination of DNA base composition by reverse-phase high-performance liquid chromatography. FEMS Microbiol Lett 25, 125-128.

Thompson, J. D., Gibson, T. J., Plewniak, F., Jeanmougin, F. \& Higgins, D. G. (1997). The CLUSTAL_X Windows interface: flexible strategies for multiple sequence alignment aided by quality analysis tools. Nucleic Acids Res 25, 4876-4882.

Tsumura, K., Hashimoto, Y., Akiba, T. \& Horikoshi, K. (1991). Purification and properties of galactanases from alkalophilic Bacillus sp. S-2 and S-39. Agric Biol Chem 55, 1265-1271.

Vedder, A. (1934). Bacillus alcalophilus n. sp.; Benevens enkele Ervaringen met sterk alcalische Voedingsbodems. Antonie van Leeuwenhoek 1, 143-147 (in Dutch).

Wayne, L. G., Brenner, D. J., Colwell, R. R. \& 9 other authors (1987). International Committee on Systematic Bacteriology. Report of the ad hoc committee on reconciliation of approaches of bacterial systematics. Int J Syst Bacteriol 37, 463-464.

Yamamoto, M., Tanaka, Y. \& Horikoshi, K. (1972). Alkaline amylases of alkalophilic bacteria. Agric Biol Chem 36, 1819-1823.

Yoshida, A., Iwasaki, Y., Akiba, T. \& Horikoshi, K. (1991). Purification and properties of cyclomaltodextrinase from alkalophilic Bacillus sp. J Ferment Bioeng 71, 226-229.

Yumoto, I., Yamazaki, K., Sawabe, T., Nakano, K., Kawasaki, K., Ezura, Y. \& Shinano, H. (1998). Bacillus horti sp. nov., a new Gramnegative alkaliphilic bacillus. Int J Syst Bacteriol 48, 565-571.

Yumoto, I., Yamaga, S., Sogabe, Y., Nodasaka, Y., Matsuyama, H., Nakajima, K. \& Suemori, A. (2003). Bacillus krulwichiae sp. nov., a halotolerant obligate alkaliphile that utilizes benzoate and $\mathrm{m}$ hydroxybenzoate. Int J Syst Evol Microbiol 53, 1531-1536.

Yumoto, I., Hirota, K., Goto, T., Nodasaka, Y. \& Nakajima, K. (2005). Bacillus oshimensis sp. nov., a moderately halophilic, non-motile alkaliphile. Int J Syst Evol Microbiol 55, 907-911. 